\title{
Pakistan's Health and Population Think Tank: a policy platform for achieving Sustainable Development Goal 3 national targets
}

\author{
Babar Tasneem Shaikh, ${ }^{1,2}$ Assad Hafeez ${ }^{1}$ and Nabeela Ali ${ }^{2}$
}

${ }^{1}$ Health Services Academy, Islamabad, Pakistan. ${ }^{2}$ John Snow Research \& Training Institute, Islamabad, Pakistan. (Correspondence to: Babar Tasneem Shaikh: shaikh.babar@gmail.com).

\begin{abstract}
In Pakistan, the Health and Population Think Tank was launched as an initiative to conduct programmes and policy analysis, as well as give an insight into the possible future policy options on various national health issues relevant to all the provinces. This forum has also served as a platform to discuss how provincial strategies could be aligned with the National Health Vision 2016-2025, which was developed with the consensus of all provinces and development partners. Main topics chosen for the round tables included local production of vaccines; social health protection; quality of care at the time of birth; human resources for health; and the challenge of tuberculosis in Pakistan. Policy briefs produced by the think tank will maximize the absorption of knowledge and will help implement the actionable items needed to speed up the progress towards achieving Sustainable Development Goal 3 (SDG3) national targets.

Keywords: health systems; health policy; SDG; think tank, Pakistan

Citation: Shaikh BT; Hafeez A; Ali N. Pakistan's Health and Population Think Tank: a policy platform for achieving Sustainable Development Goal 3 national targets. East Mediterr Health J. 2019;25(10):754-759. https://doi.org/10.26719/2019.25.10.754

Received: 06/12/18; accepted: 15/09/19

Copyright (C) World Health Organization (WHO) 2019. Some rights reserved. This work is available under the CC BY-NC-SA 3.0 IGO license (https:// creativecommons.org/licenses/by-nc-sa/3.o/igo).
\end{abstract}

\section{Introduction}

The expanded nature of the 17 Sustainable Development Goals (SDGs) shows an intricate diversity and a cross-sectorality embedded in their design. Although health has shrunk from three goals in the Millennium Development goals (MDGs) to one composite goal in SDGs, it still retains its centrality and significance with regards to the other 16 goals (1). This new position of health within the SDGs was later reflected in the National Health Vision 2016-2025 of the Government of Pakistan, which used health system strengthening building blocks as its mainstay, but also added an additional pillar on the inter-sectoral collaboration (2).

The contribution of other sectors to the development of the health sector is not a new concept; it appeared in 1978 at the Alma Ata Declaration on Primary Health Care (3), yet it was never fully realized and operationalized (4). To arrive at these commitments, it is imperative to cultivate those decision-making approaches that involve observance of research evidence (5). In Pakistan, perhaps the missing link was a structure that could look at the available evidence and conduct policy analysis for a robust advocacy. Such a role has been played in many countries by think tanks that are independent bodies and are engaged in analysis of government policies and present alternate policy options (6).

\section{What are think tanks?}

Globally, think tanks are solution and goal-oriented groups of experts, who deliberate, negotiate, research, critically analyse and provide solutions to different world problems. As they are policy-oriented, the research of think tanks delivers direct policy options and advice for the decision makers (7).

However, the most important prerequisites for any think tank to perform include a supportive policy environment, autonomy, and access to the policymakers in order to advocate for the use of evidence (8). Academic think tanks are uniquely placed to broker links between different stakeholders and these could very well assist with the cross-cutting approaches that will be required to achieve the SDG on 'Health and Well-being' (9). In Pakistan, the Health and Population Think Tank was formed and notified in 2017 under the aegis of the Ministry of National Health Services, Regulations and Coordination, which means that it will seek its guidance and advice from the ministry about the thematic areas to be examined for developing policy options. Hence, its composition and the mandate given, classifies it as a "Government-linked think tank".

\section{Context behind the establishment of the Health and Population Think Tank} A number of local factors had been affecting the performance of the national health system. Some of these include: changing disease patterns; growing inequalities and disparities between the provinces; challenges around human resources for health; increasing pressure of health care costs on patients' pockets; and questionable quality of care both in the public and private sector.

In Pakistan's constitution of 1973, health is a provincial subject and not a federal issue; yet concurrent oversight, planning, financing and service delivery has been witnessed since then due to a number of political and administrative reasons. In pursuance to the 18th 
constitutional amendment in 2011, health systems were devolved to the provinces with regard to policymaking, financing, and programme implementation. The Ministry of Health was abolished in 2011, and reestablished in 2013 as the Ministry of National Health Services, Regulations \& Coordination, with the mandate of providing a unified vision for health, interaction with donors and development partners, and reporting on international commitments such as polio eradication, SDGs, international health regulations, global health security etc. This set the national standards for medical care, curriculum, service delivery, and harnessing interprovincial coordination on health matters of national importance.

However, after 6 years it was felt that in the face of rapidly changing health systems dynamics globally and regionally, the provinces still needed technical guidance, policy advice and a roadmap. Moreover, there were public health issues not pertinent to any specific province (e.g. in-country vaccines production, tuberculosis, social health protection etc.), which needed to be addressed and deliberated upon at a joint forum with a representation of all provinces and from sectors other than health. Hence, the main vision behind forming the Health \& Population Think Tank was to foster national consensus and multi-sectoral partnership and collaboration, with the intention of reviewing, analysing, debating, brainstorming, and "building healthy public policy, in line with the spirit of Alma Ata Declaration 1978 (3), revived and celebrated recently in Aastana in 2018 (10). The Health and Population Think Tank was formed to invite technical experts from the fields of public health, hospitals, complementary medicine, education, finance, planning, social sector, private sector, NGOs, academia and bilateral and multilateral development partners. The terms of references agreed upon by the core group included:

1. Providing a platform for discussion/deliberation on priority health issues identified by the Ministry, United Nations, development partners or even by the popular press/media;

2. Reviewing current health policies nationally, regionally and globally;

3. Organizing policy discussion forum/round table discussions with relevant experts; and

4. Developing policy briefs and guidelines for knowledge uptake, as and when required by the federal ministry and the provincial departments.

\section{Process and performance so far}

The Ministry of National Health Services, Regulations and Coordination directed the Health and Population Think Tank on thematic areas for round-table discussions wherein a policy level dialogue was needed. Five critical areas of national importance had been identified for deliberation by experts in the relevant fields. These included: 1) local production of vaccines; 2 ) social health protection; 3) quality of care around the time of birth; 4) human resources for health; and 5) the tuberculosis challenge. These areas were of importance to all provinces and required a national consensus for policy decisions as well as for addressing international concerns and commitments.

For each of these areas, a concept note was prepared before the round table took place, based on recent data and facts from the field. Local, regional and international literature were also consulted. For each theme, a 1-day round table was organized to discuss the subject in length and to come up with a set of feasible options and actionable points for the ministry, departments of health, line departments, and other relevant stakeholders. Later, a short report was prepared and circulated to members for their comments. Feedback received was then triangulated with national and international peerreviewed literature, programme reports and government strategic documents. This synthesis was then used to develop a policy brief on that particular thematic area, which was passed on to the federal ministry and the provincial departments for policy decisions and further action.

\section{Round table meetings and policy lines}

A brief account of each of the areas taken up by the Health and Population Think Tank were as follows:

\section{Local production of vaccines in Palcistan}

The Expanded Program of Immunization (EPI) in Pakistan vaccinates around 6.8 million children each year by procuring vaccines at a cost of US\$18-19 million, comprising various EPI antigens and vaccines from UNICEF as well as the non-EPI vaccines from the local market. This expense causes huge encumbrance on the government exchequer. Many other regional and neighbouring countries manufacture and maintain their own requisite vaccine demand, e.g. China, Indonesia, India and the Islamic Republic of Iran. Egypt and Tunisia are primed to achieve self-reliance.

The National Institute of Health, established in 1965 , carries the mandate of vaccines and sera production for prophylactic and therapeutic use, and was supposed to cater not only to the domestic requirements, but also international demands. NIH possesses a modest infrastructure, human resource and technical capability, and for a variety of reasons its vaccine production declined to a negligible level over the years and failed to meet the current good manufacturing practices (cGMP) defined by the World Health Organization (WHO). The round table meeting aimed to generate a discussion on the prospects and potential of local or in-country production of vaccines in Pakistan to move towards selfreliance. The propositions that came out of the round table meeting were:

1. The Government must limit its role in legislation, policy and regulation to create an enabling environ- 
ment to support the local production whether public, private or under a public-private partnership.

2. For the local production of any vaccine, an analysis of viability in terms of the market and price would be considered. In addition, the exact quantities must be calculated carefully vis-à-vis population growth.

3. The Drug Regulatory Authority will be mandated for ensuring that local production meets international standards.

4. The Ministry of Health will commission a multi-faceted analysis in order to determine the vaccine production potential of the private sector; options for technology transfer (systems, processes, or end-product); and cost effectiveness, impact and return-on-investment analyses, considering counterfactual alternatives to local production.

\section{Social health protection in Pakistan}

Social health insurance is one of the most popular and authenticated organizational mechanisms for revenue raising, pooling and purchasing health services. Programmes in the Philippines, Thailand and Mexico are just a few of the success stories. With a limited public spending on health for the last six decades, the government of Pakistan has committed itself to enhance public health spending by signing up to the National Health Vision 2016-2025. The national health insurance programme has started to cater to a significant portion of the low-income sector of the population. Still, of the total health expenditure, $68 \%$ is out of pocket. It is important to note that in Pakistan, catastrophic health expenditures are responsible for a major proportion (54\%) of economic shocks faced by low-income households (11).

SDG3 includes a specific target to reach universal health coverage by 2030. Within this context, the Health and Population Think Tank convened a round table to deliberate on the issues. These included how to make current national and provincial social health protection initiatives financially sustainable; how to be more inclusive, i.e. covering all those living below the poverty line; how to extend coverage to the non-poor population groups; and how to monitor and evaluate these programmes using SDG3 targets. The round table discussion offered several policy options:

1. The National Health Insurance Programme must have legislative support in order to be sustainable.

2. The National Health Insurance Programme must work on awareness raising and demand improvement in the utilization of health services.

3. Hospitals in peri-urban areas must improve their capacity to be empanelled in the programme. Moreover, the provincial Health Care Commissions should play their role in setting quality standards.

4. More inclusiveness needs to be achieved with regard to the coverage of outdoor or ambulatory services and the cost of medicines and diagnostics.
5. Coverage for the low-income sector of the population can be implemented in two ways: either contributory or non-contributory (given the government has the resources to cover the entire population with the same premium for the same basket of services).

6. There is a need for periodic third-party monitoring of the effectiveness of the programme (supply and demand side).

\section{Quality of care around the time of birth}

Evidence shows that many women and their newborns die only because of poor care, even after reaching a health facility. With increasing numbers of women accessing health care facilities for delivery purposes, improving quality of care and patient safety have become even more critical. Poor infection control, lack of maternal and newborn death review, non-functioning medical equipment, lack of qualified staff and medical supplies are common issues in government health facilities (12). Therefore, an assessment and accountability on the quality of care (QoC), especially around the time of birth, will certainly help in achieving the SDG3 targets of maternal and newborn health. The round table discussion looked for solutions to the need to have a national/ provincial strategic framework for QoC; priority actions needed to improve QoC; and how to institute an accountability process for QoC. In this regard, action items proposed were:

1. Developing a national QoC strategic framework for subsequent adaptation by the provincial governments. The framework will:

2. guide the reorganization of $\mathrm{MNCH}$ services and the establishment of the corresponding $\mathrm{MNCH}$ services standards;

3. facilitate the tracking, monitoring, and reporting of adherence to the standards as part of the accountability measures; and

4. identify appropriate accountabilities for the different tiers of government with respect to quality of care around the time of birth.

5. Selecting and including in the Essential Health Service Package, those high impact and cost effective interventions around the time of birth.

6. Creating an exclusive budget line on improving QoC to support activities and solicit commitment from development partners.

7. Establishing women groups at the community level, hence raising demand creation for services with QoC and enabling the communities to voice their needs and aspirations.

\section{Human resource for health in Pakistan}

The health system in Pakistan faces an imbalance in the number, skills mix and deployment of the health workforce across different levels of health care, i.e. primary, secondary and tertiary. Moreover, low satisfaction levels with the workplace result in human resource (HR) attrition from public to private, and from within to outside 
the country. There are currently issues with the in-service training and continuing professional education, and licensing and renewal of licensing of health practitioners. The number of community health workers hardly covers $60 \%$ of the total population. The Health and Population Think Tank was tasked to find answers to these issues in view of the SDG3 targets, including what reforms are needed with regard to HR development, deployment, regulation, management, retention and motivation; and what are the roles of different regulatory bodies and health care commissions. The proposals put forth by the experts at the round table included:

1. Developing a comprehensive National Human Resources of Health (HRH) vision for the health sector based on National Health Vision 2016-2025.

2. Creating a HR database at the provincial and national level in order to forecast and develop the workforce.

3. Appropriating an adequate skill mix of HR production and task shifting is required, and should be linked with the Essential Health Service Package.

4. Raising the cadre of managers, regulators, administrators, specialized allied health staff and family physicians. Moreover, owing to the rapidly growing population, the number of community-based workers needs to be increased and roles must re-defined.

5. Introducing responsive management in health departments through incentives, and making rural appointments attractive.

6. Institutionalizing continuous professional development across public and private sectors, and to be conditional for re-licensing health professionals.

\section{Tuberculosis in Pakistan: a challenge remaining}

Pakistan ranks 5th among the 30 high-burden TB countries, with an incidence rate of 275 per 100000 population and a prevalence of 342 per 100 ooo population. However, only $62 \%$ of these cases could be detected and reported to the National TB Control Program (NTP) in 2015 (13). Furthermore, the country faces ever-increasing cases of drug resistance with an estimated 14000 annual cases among notified pulmonary TB patients. Pakistan stands resolute in ending $\mathrm{TB}$ and achieving the target of universal health coverage (UHC) in SDG3, and the government wants to minimize the excessive expenditure on TB treatment. Therefore, the subsequent thematic round table was organized to generate discussion on modalities to improve active vs. passive TB case detection; how can the implementation and logistic challenges be addressed; how to foster and capitalize on the public-private partnership for TB control \& eradication; and what sort of operational and implementation research is needed for TB in Pakistan. Action items proposed by the Think Tank were as follows:

1. Declaring TB as a priority disease by bringing the issue to the attention of the Prime Minister and senior ministers, thereby allowing the matter to be taken up at the Council of Common Interests.

2. Financing for $\mathrm{TB}$ to be increased at the federal level in order to close funding gaps at the provincial level. Provinces should define their financial allocations required for TB eradication in their respective Annual Development Plans.

3. Ensuring Health Care Commissions play their role in the legislation for notification of $\mathrm{TB}$ cases, especially by the private sector.

4. Increasing Investment in procurement of real time PCR/Xpert assay machines; all detected cases of TB to be tested for drug resistance through molecular amplification, along with culture and sensitivity tests for diagnosis.

\section{Discussion}

Think tanks help to ensure better governance, stakeholders' engagement and political accountability (14). Furthermore, think tanks open up avenues for learning on health policy dynamics and to recognize and overcome the implementation challenges in health systems (15). The Health and Population Think Tank's round table deliberations and the subsequent policy briefs resulted in a number of limited but precise outcomes:

- Based on the recommendations for local vaccine manufacturing in Pakistan, a summary for approval of recommendations was submitted to the Executive Committee of the National Economic Council - the highest decision-making body on economic affairs in Pakistan. Following this, the National Institute of Health has refurbished its vaccine production facility and resumed production of certain vaccines, with a plan to take up all vaccines production in due course.

- The policy brief on social health protection resulted in expansion of the Prime Minister National Health Program (PMNHP) into Phase II, which implies a scaling-up of the programme into other districts of Pakistan and inclusion of outdoor patient services in the services package. PMNHP is to be rolled out nationwide with an expanded financial safety net and will cover more than 15 million families living below the poverty line.

- The policy brief on quality of care around the time of birth resulted in consensus to develop and implement a national / provincial strategic and accountability framework on QoC.

- The development of the National HRH Vision 20182030 was refined by the recommendations made at the round table on human resources for health. The policy brief elucidated the dire need for increasing the number of nurses in the medical workforce, which was endorsed during the First National Nursing Summit held in December 2018. In addition, the strategy for the training and production of nurses was includ- 
ed as one important pillar of the National Action Plan 2019-2023.

- Following the round table on TB, it was agreed to declare TB as a priority disease for Pakistan. The Prime Minister chairing the Council of Common Interests meeting directed the provinces to enhance their budgetary allocation for TB. Meanwhile, the provinces have started developing a multi-sectoral accountability framework to control and eliminate TB.

\section{Limitations}

This paper could have benefitted from an additional perspective from stakeholders, i.e. senior officials of the ministry, donor agencies and think tank members who could comment on the performance of this forum so far. Moreover, certain themes discussed during one day only needed follow-up discussions in order to materialize more substantial recommendations.

\section{Conclusion}

The Health and Population Think Tank of Pakistan has emerged as a forum to discuss areas of high importance in public health with appropriate stakeholders' involve- ment. Henceforth, all the recommendations made by the Health and Population Think Tank could be implemented by the provinces. It is well understood that the role of the Health and Population Think Tank is not to design or develop policies, but to generate evidence for provinces on "what has worked" and "what can be contextualized" to be included in provincial strategies. It is also envisaged that a wider dissemination of the policy briefs and results of the round table meetings will maximize the absorption of knowledge and will help implement the actionable items needed to accelerate progress towards achieving SDG3 national targets. The progress made so far by the Health and Population Think Tank highlights the relevance of such platforms and its undeniable importance in addressing the complex issues in the wider public health national context. Therefore, it sets an example in the Eastern Mediterranean Region and for low and middle-income countries.

Funding: The Health and Population Think Tank received its initial funding support from the Health Systems Strengthening Component of USAID's $\mathrm{MCH}$ Project, and later from the Integrated Health Systems Strengthening and Service Delivery Activity in Pakistan.

Competing interests: None declared.

\section{Groupe de réflexion sur la santé et la population du Pakistan : plateforme politique pour la réalisation des cibles nationales liées au troisième objectif de développement durable}

\section{Résumé}

$\mathrm{Au}$ Pakistan, le groupe de réflexion sur la santé et la population a été lancé en tant qu'initiative visant à analyser les programmes et les politiques et à donner un aperçu des options politiques futures concernant diverses questions de santé nationales qui intéressent toutes les provinces. Ce forum a également servi de plateforme pour discuter de la manière dont les stratégies provinciales peuvent être alignées sur la Vision nationale de la santé 2016-2025, qui a été élaborée avec le consensus de toutes les provinces et de tous les partenaires de développement. Les principaux sujets choisis pour les tables rondes comprenaient la production locale de vaccins ; la protection sociale de la santé ; la qualité des soins au moment de la naissance ; les ressources humaines pour la santé ; et le défi que représente la tuberculose au Pakistan. Les notes d'orientation produites par le groupe de réflexion permettront l'assimilation des connaissances ainsi que la mise en œuvre des mesures nécessaires pour accélérer les progrès en vue de la réalisation des cibles nationales liées au troisième objectif de développement durable.

$$
\begin{aligned}
& \text { المحمع الفكري للصحة و السكان في باكستان: منصة سياسات لتحقيت الغايات الوطنية للهدف الثالث من أهداف } \\
& \text { التنمية المستدامة المتحية } \\
& \text { بابار تسنيم شيخخ، أسعد حفيظ، نبيلة علي } \\
& \text { الخالاصة } \\
& \text { أُطلق في باكستان المجمع الفكري للصحة و السكان، كمبادرة لوضع البرامج امته وتحليل السياسات، وكذلك لإلقاء نظرة ثاقبة على خيارات السياسات }
\end{aligned}
$$

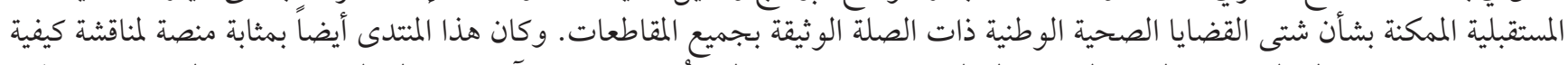

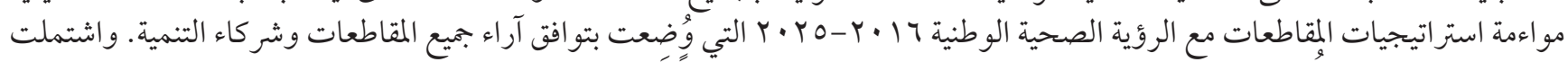

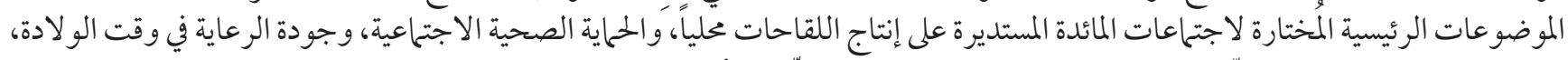

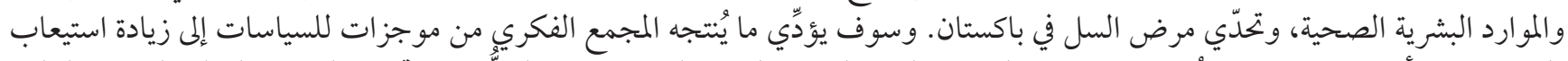

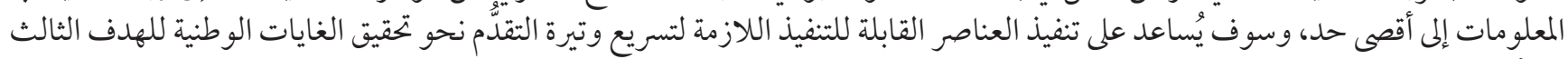

$$
\begin{aligned}
& \text { من أهداف التنمية المستدامة. }
\end{aligned}
$$




\section{References}

1. World Health Organization. From MDGs to SDGs: a new era for global public health 2016-2030. Geneva: World Health Organization; 2015.

2. Ministry of National Health Services, Regulations \& Coordination. National Health Vision 2016-2025. Islamabad: Government of Pakistan, 2016.

3. Declaration of Alma-Ata. Alma-Ata: International Conference on Primary Health Care; 6-12 September, 1978.

4. Shaikh BT, Kadir MM, Pappas G. Thirty years of Alma Ata pledges: is devolution in Pakistan an opportunity for rekindling primary health care? J Pak Med Assoc 2007; 57(5):259-261.

5. Rashidian A, Mandil A, Mahjour J. Improving evidence informed policy-making for health in the Eastern Mediterranean Region. East Mediterr Health J 2017; 23(12):793-4.

6. Shaw SE, Russell J, Greenhalgh T, Korica M. Thinking about think tanks in health care: a call for a new research agenda. Sociol Health Illn 2014; 36(3):447-61.

7. Rich A. Think tanks, public policy, and the politics of expertise. Cambridge: Cambridge University Press; 2004.

8. Bennett S, Corluka A, Doherty J, Tangcharoensathien V, Patcharanarumol W, Jesani A, et al. Influencing policy change: the experience of health think tanks in low and middle-income countries. Health Policy Plan 2012; 27(3):194-203.

9. Kickbusch I, Hanefeld J. Role for academic institutions and think tanks in speeding progress on sustainable development goals. BMJ 2017; 358:j3519.

10. Declaration of Alma-Ata. International Conference on Primary Health Care. Alma-Ata, USSR, 6-12 September, 1978.

11. Pakistan Bureau of Statistics. National Health Accounts 2015-2016. Islamabad: Government of Pakistan; 2017.

12. Iqbal S, Maqsood S, Zakar R, Zakar MZ, Fischer F. Continuum of care in maternal, newborn and child health in Pakistan: analysis of trends and determinants from 2006 to 2012. BMC Health Serv Res 2017;17(1):189.

13. Ministry of National Health Services, Regulations \& Coordination. National TB Control Program. Annual Report. Islmabad: Government of Pakistan; 2016.

14. Morton S, Pencheon D, Squires N. Sustainable Development Goals (SDGs), and their implementation: a national global framework for health, development and equity needs a systems approach at every level. Br Med Bull 2017; 124(1):81-90.

15. Jha A, Kickbusch I, Taylor P, Abbasi K. SDGs working group. Accelerating achievement of the sustainable development goals. BMJ 2016; 352:1409. 